\title{
Isolated penile lymphoedema: surgical management
}

\author{
Jimmy Shad, ${ }^{1}$ Rakesh Biswas ${ }^{2}$ \\ 1Department of General Surgery, People's College of Medical Sciences and Research Centre Bhopal, Bhopal, India; \\ 2Department of Medicine, People's College of Medical Sciences, Bhopal, India
}

Correspondence to Professor Rakesh Biswas, rakesh7biswas@gmail.com

\section{DESCRIPTION}

Lymphoedema is an abnormal collection of interstitial lymph fluid due to either congenital maldevelopment of the lymphatics or secondary obstruction. Primary penile lymphoedema is a rare occurrence. Its incidence account for approximately 1:60,000 live births. ${ }^{1}$ Generally it involves the lower limbs, but rarely the genitalia. ${ }^{2} \mathrm{We}$ report a case of primary isolated penile lymphoedema in an 8-year-old boy. The child had large penis, which was gradually progressive in size since last 3 years. There was no history of trauma or infection or any other cause of secondary lymphoedema. The child had no significant finding on general and systemic examination. Genital's examination revealed large sized penis $(12.5 \times 6.5 \mathrm{~cm})$, with no signs of inflammation, overlying temperature was subnormal (figure 1). Penis was non-tender on palpation. Scrotum was essentially normal. There were no palpable inguinal lymph nodes. All routine (haematological, biochemical and urinary) investigations were within normal limits, including negative serological test for filariasis. Ultrasonography of penis showed increase in the thickness of the dermis and subcutaneous layer with structural changes like hyperechogenic dermis and hypoechogenic subcutaneous layer. Doppler of penis excluded any vascular (arterial/venous) malformation. Although MRI and lymphoscintigraphy are important modalities to further affirm the diagnosis but

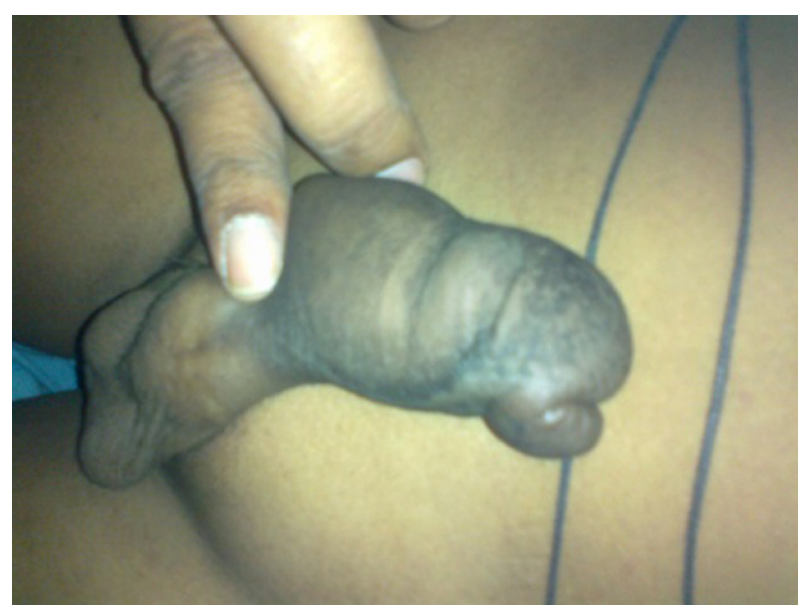

Figure 1 Preoperative photograph of patient showing large sized penis. Scrotum is normal. were not done as patient could not afford these expensive modalities. The diagnosis of primary lymphoedema of penis was made based on typical history, presentation and physical examination, aided by radiological investigations. Surgery was planned. Vertical incision was made over preputial skin reaching up to the corona extending it circumferentially, keeping a $5 \mathrm{~mm}$ fringe. Incision was deepened up to the bucks fascia and penis was degloved up to the base (figure 2). The whole of involved oedematous tissue including skin (shaft and prepuce) was resected. The skin around the penile base was mobilised and primary approximation was done (figure 3 ). The patient was catheterised. The patient recovered well. He was discharged on third day after removing catheter. On follow-up 4 months after surgery, the cosmetic result was excellent with full patient satisfaction. Histopathological examination showed non-specific chronic inflammation with areas of epidermal thickening and dermal fibrosis. Focal perivascular lymphocytic aggregates were seen. On systematic review of literature surgical resection of involved tissue and covering with split skin grafting has been described for similar conditions. We adopted the technique of avoiding skin graft in the present case which gave us good cosmetic results without any complications such as graft rejection, infection or contracture with benefits of less morbidity, less hospital stay and cost eventually.

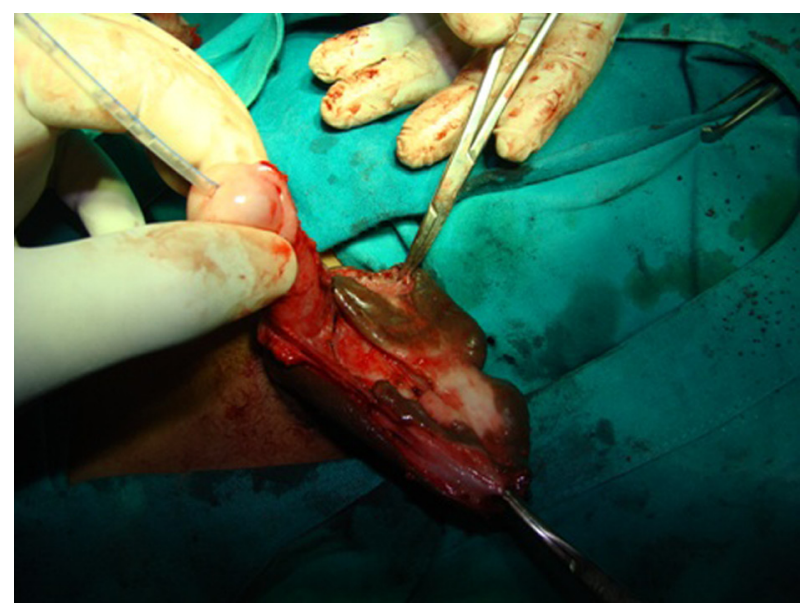

Figure 2 Intraoperative photograph showing penis degloved up to the base. 


\section{BMJ Case Reports}

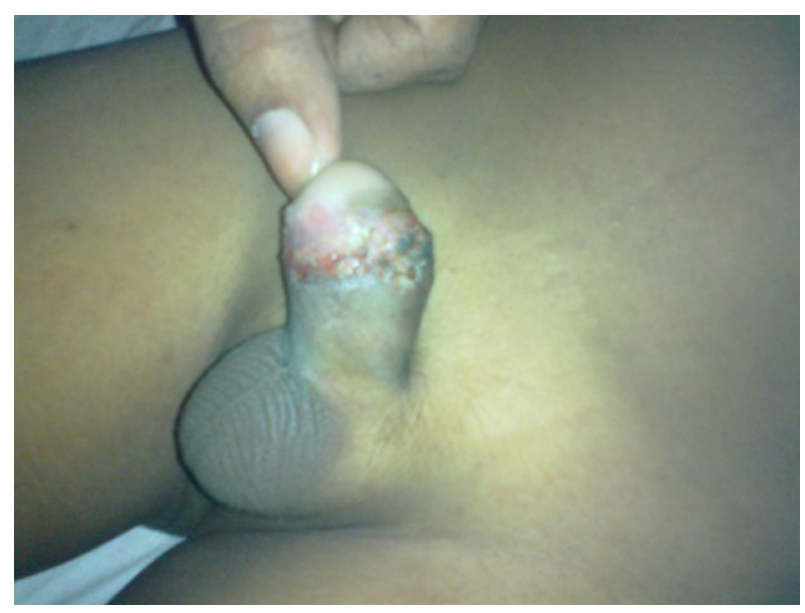

Figure 3 Postoperative photograph showing normal looking penis with slight induration at the suture line.

\section{Learning points}

The rare occurrence of genital primary lymphoedema especially isolated penile lymphoedema in children lead us to report this case.

- Treating such rare cases should be individualised besides the prescribed traditional methods.

Competing interests None.

Patient consent Obtained.

\section{REFERENCES}

1. Smeltzer DM, Stickler GB, Schirger A. Primary lymphedema in children and adolescents: a follow-up study and review. Pediatrics 1985;76:206-18.

2. Ross JH, Kay R, Yetman RJ, et al. Primary lymphedema of the genitalia in children and adolescents. J Urol 1998;160:1485-9.

3. Shenoy VG, Jawale SA, Oak SN, et al. Primary lymphedema of the penis: surgical correction by preputial unfurling. Pediatr Surg Int 2001;17:169-70.

This pdf has been created automatically from the final edited text and images.

Copyright 2011 BMJ Publishing Group. All rights reserved. For permission to reuse any of this content visit

http://group.bmi.com/group/rights-licensing/permissions.

BMJ Case Report Fellows may re-use this article for personal use and teaching without any further permission.

Please cite this article as follows (you will need to access the article online to obtain the date of publication).

Shad J, Biswas R. Isolated penile lymphoedema: surgical management. BMJ Case Reports 2011;10.1136/bcr.11.2011.5128, Published XXX

Become a Fellow of BMJ Case Reports today and you can:

- Submit as many cases as you like

- Enjoy fast sympathetic peer review and rapid publication of accepted articles

- Access all the published articles

- Re-use any of the published material for personal use and teaching without further permission

For information on Institutional Fellowships contact consortiasales@bmjgroup.com

Visit casereports.bmj.com for more articles like this and to become a Fellow 